\title{
Two new Gomphonema Ehrenberg (Bacillariophyceae) species from Macedonia and comparison with type material of G. brebissonii KüTZING
}

\author{
Danijela Mitić-Kopanja ${ }^{1}$, Carlos E. Wetzel ${ }^{2}$, Luc Ector ${ }^{2} \&$ Zlatko Levkov $^{1 *}$
}

\author{
${ }^{1}$ Institute of Biology, Faculty of Natural Sciences, Ss Cyril and Methodius University, Gazi Baba bb, 1000 \\ Skopje, R. Macedonia; *Corresponding authore-mail: zlevkov@pmf.ukim.mk \\ ${ }^{2}$ Department of Environment and Agro-biotechnologies (EVA), Public Research Centre - Gabriel Lippmann, \\ Rue du Brill 41, L-4422 Belvaux, Luxembourg
}

\begin{abstract}
A large study on Gomphonema Ehrenberg species from Macedonia recently has been started. In this article two species are presented having unique set of characters than already known species and therefore are described as new species. The comparison was made using type material of G. brebissonii KützING and G. gautieri (Van Heurck) Lange-Bertalot et Metzeltin. Gomphonema scardicum sp. nov. resembles $G$. montanum (SChUmann) Grunow and G. brebissonii KütZING with respect to the valve outline and size. Main differential characters of $G$. scardicum are the cuneate shape of the headpole and less pronounced constriction near the head pole. Similarly, G. gautieriforme sp. nov. differs from G. gautieri with respect to the valve outline and the shape of the head pole. The valves of $G$. gautieriforme are almost rhombic in outline and gradually narrowing towards the footpole. The head pole of G. gautieriforme is rounded and cuneate opposite to truncate and apiculate in G. gautieri.
\end{abstract}

Key words: Gomphonema, diatoms, taxonomy, new species, Macedonia, type material

\section{INTRODUCTION}

EHRENBERG (1832) described the genus Gomphonema to include six taxa. The diatom genus name Gomphonema EHRENBERG (1832) is conserved against that of Gomphonema C. Agardh (1824), the latter having no designated generitype. Since then, it has received considerable attention resulting in more than 1000 names (FourTANIER \& KocioleK 2011) and more than 120 species having been described from various parts of the world in the last decade. More recently, several species of Gomphonema have been typified (JAHN 1986; Lange-Bertalot \& Genkal 1999; Reichardt 1999; JAHN \& KUSBER 2004) or type material has been observed in detail (ReICHARDT 2001, 2005; Novais et al. 2009; VAN DE VIJVER et al. 2013).

Gomphonema is considered heterogeneous (Reichardt 2007; Levkov \& Williams 2011) and paraphyletic (KermarRec et al. 2011). On other side, the molecular studies showed that Gomphonema is monophyletic (BRUDER \& MEDLIN 2008; p. 313), although G. micropus Kützing was separated from other species. Several genera have been separated from Gomphonema based on ultrastructural differences (Medlin \& Round 1986; Lange-Bertalot 1995). Additionally, several species around G. olivaceum (HORNEMANN) BRÉBISSON and G. quadripunctatum Østrup have been transferred to the genus Gomphoneis
Cleve(Dawson 1974; Ross \& Sims 1978; Ohtsuka 2002; Tuл 2005). The most recent concept of Gomphonema sensu stricto comprises species with linear to linearlanceolate and more or less heteropolar valves, with broader head and narrower base pole, striae uniseriate or biseriate and single (rarely two) stigma present in the central area (Round et al. 1990). Species without stigma or with four stigmoids have been transferred into other genera, like Gomphoseptatum Meduin, Pseudogomphonema MeduIn, Gomphosphenia LANGEBertalot, Gomphoneis Cleve (Medlin \& Round 1986; Lange-Bertalot 1995; Kociolek et al. 2013).

Gomphonema has received relatively little attention in Macedonia, with exception of studies on lakes Ohrid and Prespa. Hustedt (1945), in his study of diatoms from Balkan Peninsula, described four new taxa from the lakes Ohrid and Prespa. More recently, Lange-Bertalot \& Reichardt (in Lange-Bertalot 1993), Levkov et al. (2007) and Levkov \& Williams (2011) described additional 10 new species from Lake Ohrid. According to the check list of diatoms of lakes Ohrid and Prespa (Levkov \& Williams 2012), in both lakes almost 60 Gomphonema taxa have been reported. With respect to other localities in Macedonia, LevKov \& Stojanovski (2002) recorded seven Gomphonema taxa from Lake Doiran, while Levkov et al. (2005) reported 21 Gomphonema species from Shara and Nidze mountains. Recently a detailed taxonomic study 
of Gomphonema species from Macedonia was begun (e.g. LeVkov \& Williams 2011). This paper contains the first results of detailed observations of two species which posses unique set of characters that distinguish them from all known taxa. One was previously identified as $G$. brebissonii KützING by Levkov et al. (2005) but after observations of the type material, it was found that the species from Shara Mountain has morphological characters that clearly separate it from the type and other populations of G. brebissonii.

\section{Materials and Methods}

The samples from Macedonia examined in this study have been collected during two different campaigns. One of the samples was collected in 2003 from a small stream above Lake Crno on Mountain Shara, Macedonia, ca $2300 \mathrm{~m}$ above sea level, while the second sample was collected in 2013 from the drainage channel of Katlanovo wetland, near village Taor, Macedonia (ca 240 m.a.s.1.). These two samples had a high abundance of Gomphonema species used for detailed light microscope (LM) and scanning electron microscope (SEM) observations. Original material of G. brebissonii from Falaise (Caen, Calvados department, Basse-Normandie region, France, leg. Brébisson) was obtained for SEM analyses from the Friedrich Hustedt Centre for Diatom Study, Bremerhaven (BRM RBH2007, in coll. Rabenhorst), while slides made from the type material were loaned from the Natural History Museum in London (BM 18641 and BM 18694 in coll. Kützing and BM 13194 in coll. Deby).

The organic content of the raw material was removed from the samples by the method of acid digestion, with the addition of $2 \mathrm{ml}$ of supersaturated solution of $\mathrm{K}_{2} \mathrm{MnO}_{4}$ and $4 \mathrm{ml}$ of $\mathrm{HCl}$ to a small (ca. $2 \mathrm{ml}$ ) subsample. Permanent slides were mounted with $\operatorname{Naphrax}^{\circledR}$. Slide observations were performed with a Nikon E-80i light microscope, and photomicrographs were taken with a Nikon Coolpix 600 digital camera. For scanning electron microscopy (SEM), a small amount of the suspensions were filtered and rinsed with additional deionised water through a $10 \mu \mathrm{m}$ Isopore $^{\mathrm{TM}}$ polycarbonate membrane filter (Merck Millipore ${ }^{\mathbb{R}}$ ) with a vacuum pump. Filters were mounted on aluminum stubs using double side carbon tape and coated with platinum (30 $\mathrm{nm}$ ) using a BAL-TEC MED 020 Modular high vacuum coating system for $30 \mathrm{~s}$ at $100 \mathrm{~mA}$. An ultra-high-resolution analytical field emission (FE) scanning electron microscope Hitachi SU-70 (Hitachi High-Technologies, Europe, $\mathrm{GmbH}$ ) operated at $5 \mathrm{kV}$ and $10 \mathrm{~mm}$ distance was used for the analysis. SEM images were taken using the lower (SE-L) detector signal.

The type slides are deposited at the Macedonian National Diatom Collection (MKNDC) at the Institute of Biology in Skopje, Macedonia and isotype slides are deposited at the Natural History Museum in London (BM) and at the Friedrich Hustedt Centre for Diatom Study, Bremerhaven (BRM).

\section{Observations}

\section{Gomphonema brebissonii Kützıng (Figs 1-15, 18-} 24)

Light microscopy (Figs 1-15): Frustule in girdle view wedge shaped. Valves heteropolar, narrowly clavate to linear with slightly undulate margins and narrowly rhomboid and obtusely rounded on the headpole and acutely rounded footpole. Headpole slightly wider than central part of valve. Constriction between headpole and mid-valve visible, but not distinct. Valve length 31-55 $\mu \mathrm{m}$, valve width 7.5-9.5 $\mu \mathrm{m}$ in widest part, 7.2-8.5 $\mu \mathrm{m}$ in mid-valve. Axial area moderately broad, linear to narrowly lanceolate. Central area irregular to elliptical, narrow, bordered by one (rarely two) shortened stria on each side. One isolated stigma present in central area, separated from shortened central stria. Raphe lateral with small central pores. Transapical striae radiate near mid-valve becoming more strongly radiate towards poles, 9-11 in $10 \mu \mathrm{m}$. Puncta of striae not visible with LM. Striae less distantly spaced close to footpole.

Scanning electron microscopy (Figs 18-24): Externally, raphe branches clearly undulated (Figs 18, 20). Distal ends unilaterally deflected onto valve mantle (Figs 23, 24). Proximal raphe endings expanded, teardrop-shaped, very weakly deflected opposite to stigma (Fig. 19). At footpole, distal raphe bisecting well developed apical pore field (APF) composed of round porelli, structurally different from areolae, extending on valve mantle. Narrow hyaline area present between last stria and APF (Fig. 24). External stigma opening round, situated at end of central stria (Fig. 19). Striae uniseriate throughout, interrupted near valve face/ mantle junction, continuing onto mantle (Fig. 18). Areolae c-shaped, slightly sunk into valve face formed by siliceous flaps occluding the areolar openings (Figs 19, 23, 24). Mantle striae composed of c-shaped areolae terminating by several small, c-shaped or slitlike areolae (Fig. 18). Internally, small pseudosepta present, clearly visible at both poles (Fig. 21). Proximal raphe endings recurved along the outer edges of the raised central nodule (Fig. 22). Distal raphe endings terminating on small helictoglossae (Fig. 21). Stigma opening elongated, slit-like, relatively small (Fig. 22). Areolae located in foraminal rows with small round to c-shaped. Siliceous flaps covering most of the opening are visible inside the areolar opening (Fig. 26).

Notes: Lange-Bertalot \& Genkal (1999; p. 52) provided formal typification of $G$. brebissonii illustrating it with two specimens (op. cit. figs 68: 8,9). Both images were reproduced in REICHARDT (1999; figs 56: 12, 13) in his revision of selected Gomphonema species complexes. According to REICHARDT (1999; p. 47) the population from the type material is characterized by following valve measurements: valve length $30-86 \mu \mathrm{m}$, width at headpole $8.3-14.0 \mu \mathrm{m}$, 

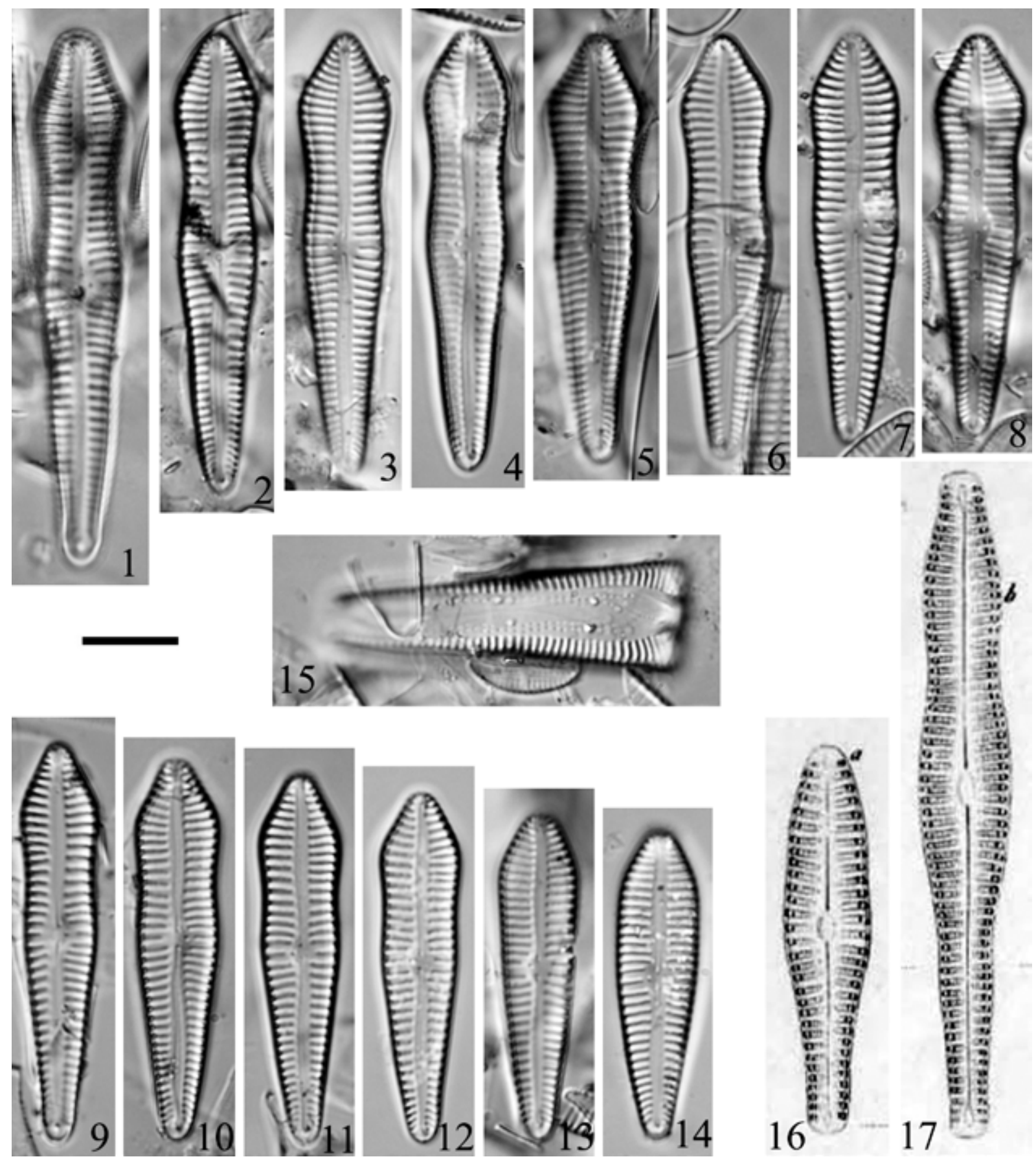

Figs 1-15. Gomphonema brebissonii, LM, Falaise, France: (1-14) diminution series; (15) frustule in girdle view. Figs 16, 17. Gomphonema acuminatum var. montanum Schumann modified original drawings (Schumann 1867, figs 35a, b). Scale bar $10 \mu \mathrm{m}$.

width at mid-valve $7.6-11.4 \mu \mathrm{m}$ and striae $9-11$ in 10 $\mu \mathrm{m}$.

\section{Gomphonema scardicum sp. nov. (Figs 25-53)}

Light microscopy (Figs 25-44): Valve heteropolar, linear-lanceolate with the largest valve width near midvalve with narrowly rounded to cuneate headpole, and acutely rounded footpole. Larger valves with weakly constricted margin between headpole and mid-valve, constriction in smaller specimens indistinct. Largeand medium-sized specimens inflated at mid-valve.
Valve length $36-63 \mu \mathrm{m}$, width 7.0-8.0 $\mu \mathrm{m}$ at headpole, 7.5-9.5 $\mu \mathrm{m}$ at mid-valve (widest part in mid-valve). Axial area narrow, linear-lanceolate, ornamented with shallow, irregularly arranged depressions. Central area small, formed by shortening of single central stria on both valve sides. One isolated stigma present in central area, located near the mid-valve, and separated from long, central stria. Raphe clearly lateral, weakly undulated with simple, slightly expanded central raphe endings. Transapical striae coarse, parallel in midvalve 9-12 striae in $10 \mu \mathrm{m}$, becoming radiate towards 

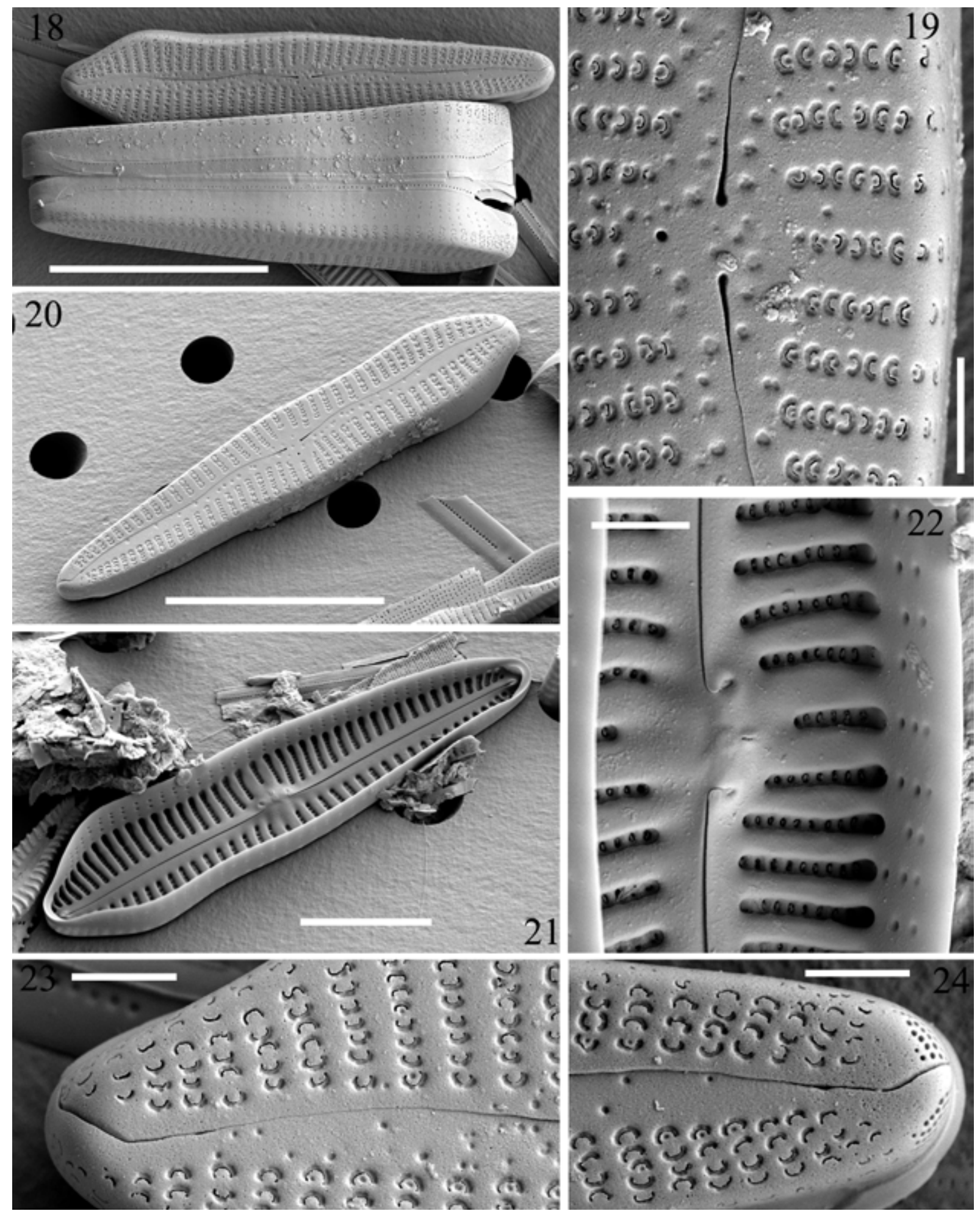

Figs 18-24. Gomphonema brebissonii, SEM, type material, Falaise, France: (18) external view of the whole valve and frustule; (19) detailed view of mid-valve showing the external opening of stigma; (20) external view of the whole valve; (21) internal view of the whole valve; (22) detailed internal view of the mid-valve showing the proximal raphe fissures and opening of the stigma; (23) detailed view of the headpole; (24) detailed view of the footpole. Scale bar $20 \mu \mathrm{m}(18,20), 10 \mu \mathrm{m}(21), 2 \mu \mathrm{m}(19,22-24)$. 


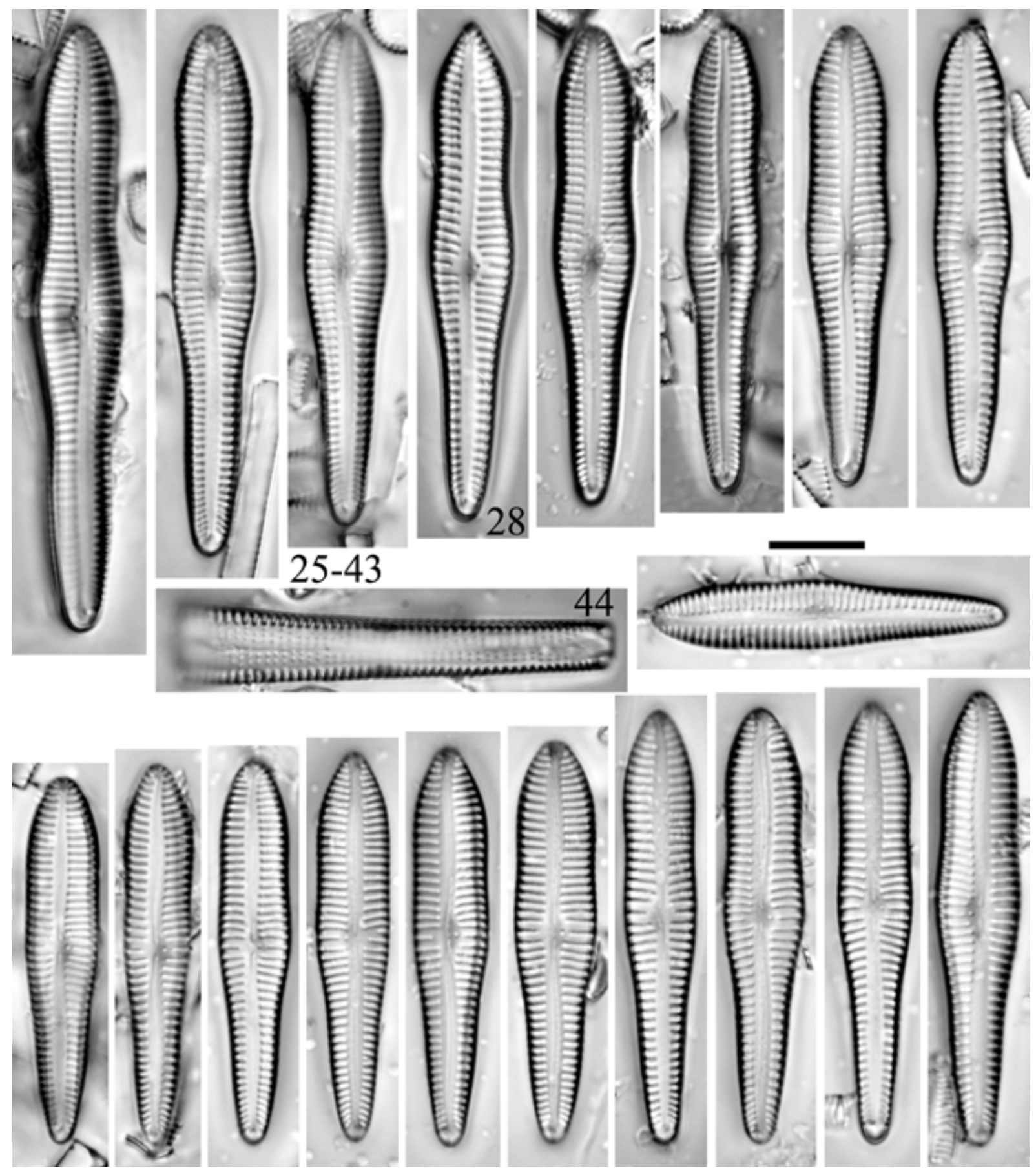

Figs 25-44. Gomphonema scardicum sp. nov., LM, mosses, spring above Lake Crno, Shara Mountain, Macedonia: (25-43) diminution series; (44) frustule in girdle view. Scale bar $10 \mu \mathrm{m}$.

footpole. Striae denser at footpole, $12-15$ in $10 \mu \mathrm{m}$. Areolae distinguishable, around $22-25$ in $10 \mu \mathrm{m}$.

Scanning electron microscopy (Figs 45-53): Externally, raphe branches distinctly undulate (Figs 45, 50). Distal raphe ends deflected first towards stigma-bearing side and than deflected on opposite side, extending onto valve mantle (Figs 52, 53). At footpole, distal raphe bisecting well developed apical pore field, of round porelli, structurally different from areolae, extending on valve mantle. Proximal raphe endings simple without marked central pores, curved towards stigma (Fig. 50). External stigma opening round, situated at end of central stria (Fig. 50). Areolae c-shaped to reniform (Figs 50, 52, 53), occluded by siliceous flaps. Striae uniseriate throughout, interrupted near valve face/mantle junction and continuing onto valve mantle (Fig. 50). Striae on valve mantle adjust to face/mantle junction composed of large c-shaped areolae, while towards bottom composed of small, c-shaped to slit-like areolae (Fig. 46). Mantle striae at headpole longer than striae on near footpole. Near 

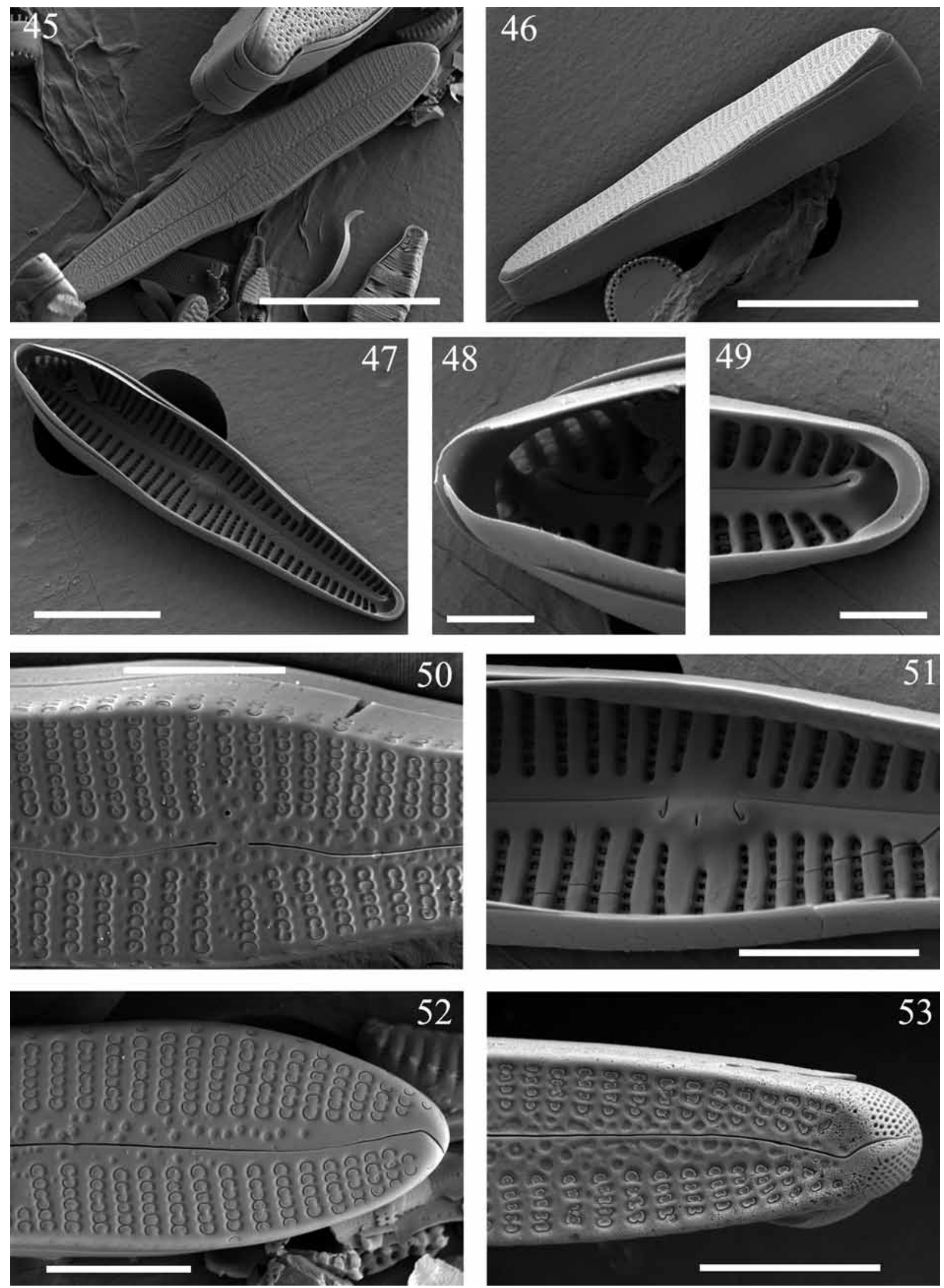

Figs 45-53. Gomphonema scardicum sp. nov., SEM: (45) external view of the whole valve; (46) frustule in valvar and girdle view; (47) internal view of the whole valve; (48) internal view of the headpole; (49) internal view of the footpole; (50) external view of the mid-valve showing the proximal raphe fissures and stigma; (51) internal view of the mid-valve showing the proximal raphe fissures and stigma; (52) detailed view of the headpole; (53) detailed view of the footpole. Scale bar $20 \mu \mathrm{m}(45,46), 10 \mu \mathrm{m}(47), 2 \mu \mathrm{m}(48,49), 5 \mu \mathrm{m}(50-53)$. 

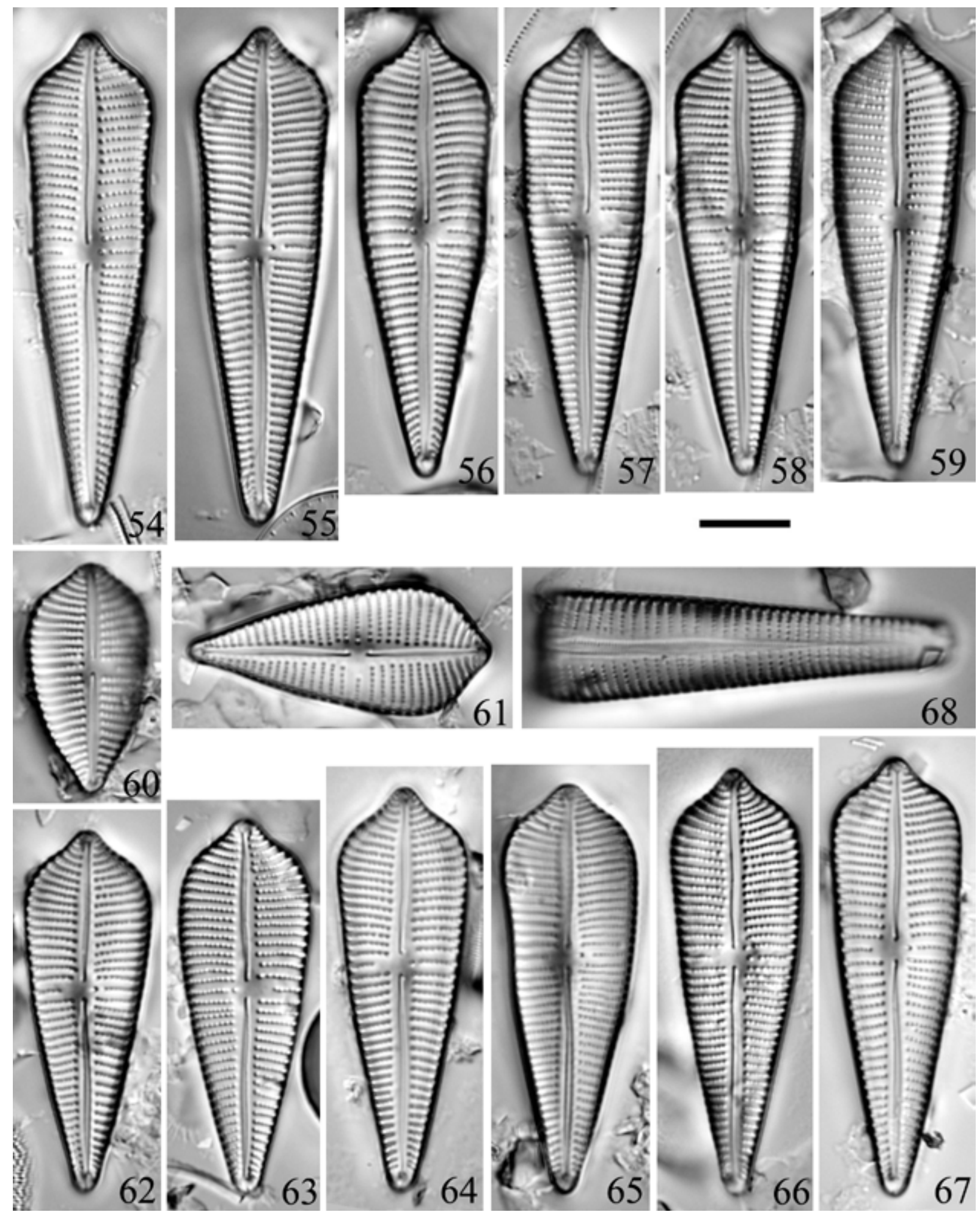

Figs 54-68. Gomphonema gautieriforme sp. nov., LM, on macrophytes, drainage channel of Katlanovo wetland, Macedonia, diminution series. 

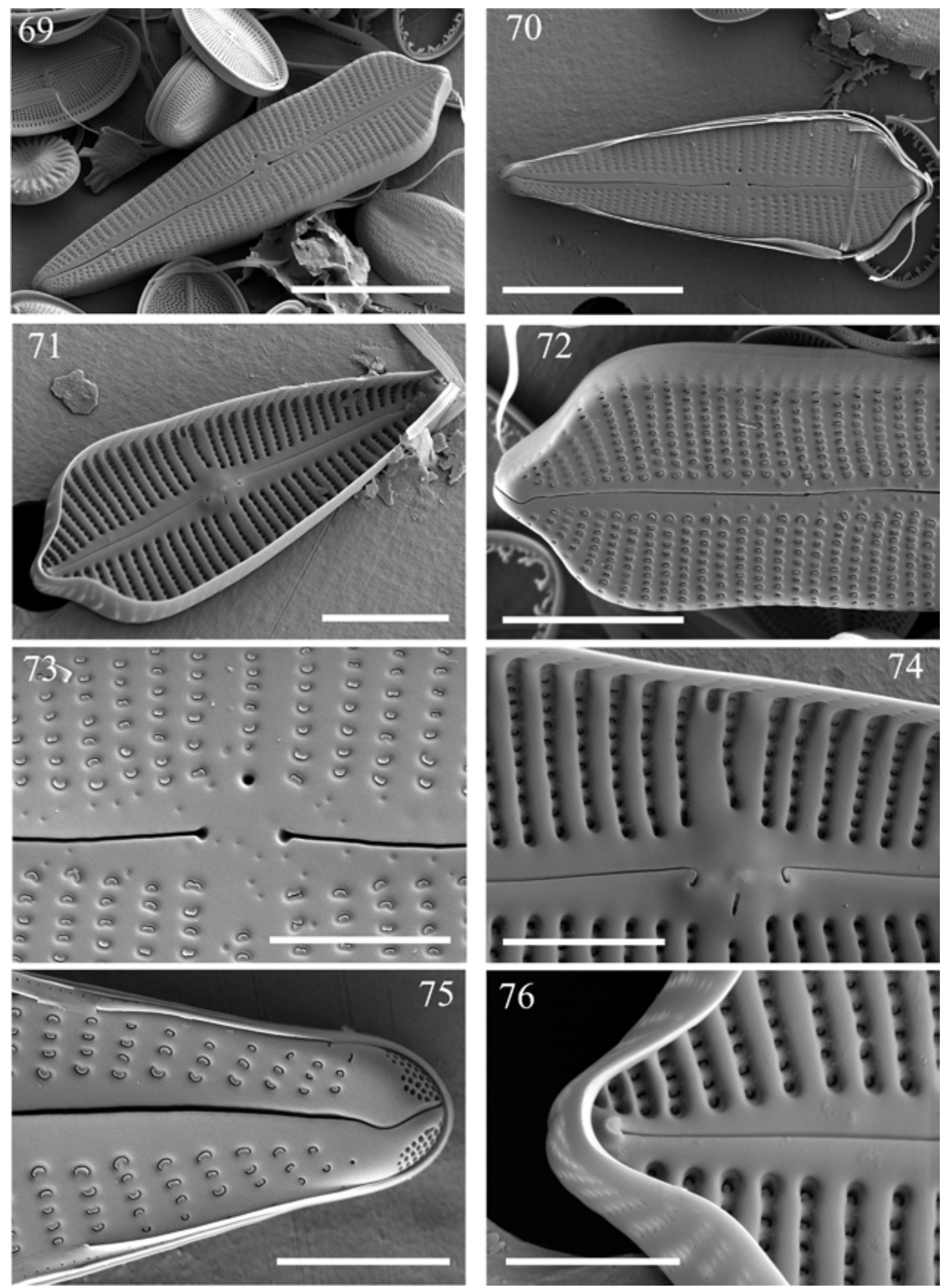

Figs 69-76. Gomphonema gautieriforme sp. nov., SEM: $(69,70)$ external view of the whole valve; $(71)$ internal view of the whole valve; $(72)$ detailed external view of the headpole; (73) external view of the mid-valve showing the proximal raphe fissures and stigma; (74) internal view of the mid-valve showing the proximal raphe fissures and stigma; (75) detailed view of the footpole; (76) internal view of the headpole. Scale bar $20 \mu \mathrm{m}(69,70), 10 \mu \mathrm{m}(71,72), 5 \mu \mathrm{m}(73,74), 4 \mu \mathrm{m}(75,76)$. 
head and footpole small c-shaped areolae absent at end of mantle striae. Narrow hyaline area present at foot pole located between last stria and APF. Internally, small pseudosepta present at both poles (Figs 48, 49). Proximal raphe endings recurved and angular along outer edges of raised central nodule (Figs 47, 51). Distal raphe endings terminating on small helictoglossae (Figs 48, 49). Interstriae with same width as striae. Areolae with round to reniform internal openings. Towards valve margin, siliceous flaps covering most of the opening visible inside the areolar opening. Stigma with small, elongated opening.

Holotype (designated here): Slide 003039/A in MKNDC. Holotype specimen is represented by Fig. 28.

Isotype: Slide BRM ZU9/72.

Type material: Mosses, stream above Lake Crno, Shara Mountain. 41 ${ }^{\circ} 55^{\prime} 34$ 'N, 2047'25” E, Coll. date: 07.08.2003. Leg. Z. Levkov.

Etymology: The specific epithet (scardicum) refers to the Latin name of the mountain Shara (Scardus).

Notes: Gomphonema scardicum resembles $G$. montanum (SCHUMANN) GRUNOw (= G. acuminatum var. montanum SCHUMANN 1867, p. 67, figs 3: 35a, b) and G. brebissonii KÜTZING with respect to valve outline. However, the type material of G. montanum was not available for this study, and therefore comparison has been made with the original drawing and published interpretations (e.g. HustedT 1930, fig. 707; PATRICK \& ReImer 1975, fig. 16: 7; KrAmmer \& LANGe-Bertalot 2004, figs 83: 16-18). Elmore (1921, figs 540-553) depicted several valves of $G$. montanum, but very likely none of them represent $G$. montanum sensu stricto. According to PATRICK \& ReImer (1975, p. 122) the valves of $G$. montanum have rostrate-rounded to almost truncate apices, corresponding to the original drawing (ScHUMANN 1867, figs 3: 35a, b here reproduced as Figs 15, 16). Valves with similar morphological features are depicted in Krammer \& LANGE-BERTALOT (1986, fig. 163: 6; 2004, figs 83: 16-18). However, all of these can be easily differentiated from $G$. scardicum by the shape of the headpole. Gomphonema montanum var. genuinum ANT. MAYer (1913, fig. 13: 30; 1928, fig. $3: 4,5)$ has broadly cuneate headpole and protracted at the top, opposite to narrowly cuneate headpole in G. scardicum. Gomphonema montanum var. media $\mathrm{f}$. typica ANT. MAYER (1928, figs 3: 4,5), has broadly of obtusely rounded headpole, which makes for an easy differentiation between these two taxa. Gomphonema montanum var. turriforme CLEVE-EULER (1955, figs $1276 \mathrm{a}, \mathrm{b})$ has wider valves $(\mathrm{W}=8-10 \mu \mathrm{m})$ and wider headpole $(8.5-9.0 \mu \mathrm{m})$ with different shape (rhombic).

Gomphonema brebissonii has a different valve outline with the widest part of the valve near the headpole, opposite to G. scardicum, where the widest part of the valve is in the mid-valve. Additional differences can be seen in the shape of the headpole. In $G$. brebissonii the headpole is narrowly rhomboid and obtusely rounded on the top, opposite to narrowly rounded to cuneate headpole. Other population of $G$. brebissonii, like those depicted in REICHARDT (1999, figs 27: 1-13, 56: 1-14), have much broader valve apices which are distinctly separated from the rest of the valve by the prominent constriction.

The valves of $G$. acuminatum var. intermedia Grunow in VAN Heurck (1880, fig. 23: 21) have a distinct constriction towards the headpole and distinct, broadly rounded and shortly apiculate headpole. Gomphonema acuminatum var. clavus (BRÉBISSON) Grunow in VAN Heurck (1880, fig. 23: 20) may be smaller specimens of $G$. acuminatum EHRENBERG, since it has a distinct constriction towards headpole and as well as distinct shoulders. Gomphonema trigonocephalum EHRENBERG (1854, pl. 6/1: fig. 36) has a different valve outline (rhombic) and shape of the valve apices (broadly cuneate) compared to $G$. scardicum. Gomphonema isabellae VAN DE VIJVER in VAN DE VIJVER \& MCBRIDE (2006, figs 1-19) is characterized by valves distinctly constricted towards the headpole, broadly rhomboid with a protracted to cuneately rounded top. These features make the distinction with G. scardicum straightforward.

The most similar specimens to G. scardicum are depicted in FogED (1982, figs 31: 8, 9) under name "Gomphonema acuminatum EHR. var. trigonocephala (Ehr.) Grun. Transition to var. brebissonii (KüTz.) Cleve". These specimens from Bornholm (Denmark) are most likely specimens of G. scardicum.

\section{Gomphonema gautieriforme sp. nov. (Figs 54-76)} Light microscopy (Figs 54-68): Valve clearly heteropolar, clavate with largest valve width near headpole. Headpole broadly rounded, cuneate. Valves with indistinct shoulders and gradually narrowing towards acute footpole. Valves weakly inflated at mid-valve. Valve length $25-55 \mu \mathrm{m}$, width $13.0-15.0$ $\mu \mathrm{m}$ at headpole, $12.0-13.5$ at mid-valve. Axial area narrow, linear-lanceolate. Central area small, formed by shortening of single central stria. One isolated stigma present in central area, located near the midvalve, and separated from long, central stria. Raphe clearly lateral, weakly undulated with simple, slightly expanded central raphe endings. Transapical striae coarse, parallel in mid-valve 9-12 striae in $10 \mu \mathrm{m}$, becoming radiate towards headpole and footpole. Striae denser at footpole and headpole $12-15$ in $10 \mu \mathrm{m}$. Areolae distinguishable, around 18-22 in $10 \mu \mathrm{m}$.

Scanning electron microscopy (Figs 69-76): Externally, raphe branches slightly undulate (Figs 69, 70). Distal raphe ends deflected first towards stigma-bearing side and than deflected on opposite side, extending onto valve mantle (Figs 72, 75). At footpole, distal raphe bisecting well developed apical 
pore field (Fig. 75). Proximal raphe endings expanded, pore-like, curved towards stigma (Fig. 73). External stigma opening rounded, situated at end of central stria (Fig. 73). Areolae c-shaped to reniform (Figs 72, $73,75)$, occluded by siliceous flaps. Striae uniseriate, not interrupted near valve face/mantle junction and continuing onto valve mantle (Fig. 72). Striae on valve mantle entirely composed of c-shaped areolae. Areolae on valve mantle with similar size and shape as areolae on valve face (Fig. 69). Narrow hyaline area present at foot pole located between last stria and APF. Apical pore field composed of round porelli, structurally different from areolae (Fig. 75).

Internally, small pseudosepta present, clearly visible at footpole, less developed at headpole (Fig. 76). Proximal raphe endings hooked, located on raised central nodule (Figs 71, 74). Distal raphe endings terminating on small helictoglossae (Fig. 76). Stigma with elongated, slit-like opening (Fig. 74). Interstriae with same width as striae (Figs 74, 76). Areolae with round to reniform internal openings. Towards valve margin siliceous flaps covering most of opening visible inside the areolar opening.

Holotype (designated here): Slide 006877/A in MKNDC. Holotype specimen is represented by Fig. 55.

Isotype: Slide BRM ZU9/73.

Type material: Macrophytes, drainage channel of Katlanovo wetland, near village Taor. 41 ${ }^{\circ} 54^{\prime} 06^{\prime \prime} \mathrm{N}$, 21³6'44” E, Coll. date: 15.08.2013. Leg. Z. Levkov.

Etymology: The specific epithet refers to the similarity in valve morphology with G. gautieri (VAN HEURCK) LANGE-Bertalot et Metzeltin.

Notes: Gomphonema gautieriforme resembles $G$. gautieri (= G. augur var. gautieri VAN HEURCK, 1885, p. 124) with respect to valve size and shape. The latter species was recently typified by VAN DE VIJVER et al. (2013). A single valve was recorded on the type slide (slide V-11-A6) and illustrated (op.cit. fig. 1). According to VAN DE VIJVER et al. (2013) the valve is clearly heteropolar, clavate with the largest valve width near the truncate and apiculate headpole, and valve margin constricted between the headpole and the valve middle. Gomphonema gautieriforme can be differentiated from $G$. gautieri by its valve outline and the shape of its headpole. The valve margin in $G$. gautieriforme is very weakly constricted in the largest specimens but unconstricted in medium-sized and smaller specimens; in G. gautieri the valve is clearly constricted. The headpole in $G$. gautieri is truncate and apiculate, while the headpole in G. gautieriforme is rounded and cuneate. Gomphonema augur sensu Krammer \& LANGE-Bertalot (1985, figs 36: 1-14) is very likely heterogeneous and only fig. $36: 14$ is $G$. gautieri sensu stricto; the other specimens belong to G. augur sensu stricto (figs 36: 11-13) or unknown
Gomphonema taxa (figs 36: 1-10).

The valves of G. gautieri sensu Metzeltin et al. (2009, figs 164: 1-9) share the morphological features of the type specimen (VAN DE VIJVER et al. 2013, fig. 1) except valve width. Additionally, some specimens have a lower stria density, but the overall morphology remains the same as specimens with higher stria density. Gomphonema gautieri sensu CHOLNOKY (1957, figs 43, 44) = Gomphonema constrictum var. gautieri (VAn Heurck) Cholnoky, differs from the type and $G$. gautieriforme by the valve outline (distinct constriction towards the headpole) and shape of head pole (almost truncate and weakly cuneate on the top).

Gomphonema gautieriforme resembles $G$. augur EHRENBERg sensu Krammer \& LANGE-Bertalot (1986, fig. 157: 7) but the latter has clearly apiculate (not cuneate) headpole. Typification of $G$. augur was undertaken by JAHN \& KUSBER (2004, fig. 25) based on a specimen from Puy-de-Dôme, France since it was a better fit to the current taxonomic concept of the species, in contrast to the specimens present in Mexican material which was first used for the invalid description of the species (EHRENBERG 1838). Recently type material of $G$. augur was observed by VAN DE ViJVER et al. (2013, figs 6-11, 27-41). The valves of G. augur are characterized with broadly rounded and apiculate headpole without shoulders; the valve margins are neither constricted nor inflated, but the valve width gradually narrowing towards the acute footpole; valve length 36.8-38.8 $\mu \mathrm{m}$, width 12.5-13.1 $\mu \mathrm{m}$. Both $G$. augur and $G$. gautieriforme can be differentiated by the shape of the head pole. Another taxon from this group was observed by JAHN (1986, figs 3: 25-42) and identified as G. cf. augur. Gomphonema gautieriforme can be easily differentiated from $G$. augur by the valve shape: the valve margin in most of the specimens is undulated, and the widest part of the valve is in the middle, and not at the headpole.

Gomphonema sphaerophorum EHRENBERG has similar valve size as G. gautieriforme, but it possesses broadly rounded and capitate headpole (UEYAMA \& KoBAYASI 1988), in contrast to cuneate headpole in $G$. gautieriforme.

In general, the valve length and stria density of $G$. brebissonii and G. gautieriforme overlap, but both taxa can be easily differentiated by the shape of the head pole and valve apex. The larger valves of $G$. brebissonii are clearly inflated in the mid-valve and this inflation is with almost same width as the headpole. In $G$. gautieriforme the widest part of the valve is found at the head pole with the valve width gradually narrowing towards the footpole. Additionally, the differences can be noticed in the morphology of the areolae of the striae on the valve mantle. In G. brebissonii the mantle striae near the valve face/mantle junction are composed of $\mathrm{c}$-shaped areolae and terminating by several small, c-shaped or slit-like areolae (Fig. 18). In $G$. gautieriforme the mantle striae are entirely 
composed of c-shaped areolae with similar size and shape as valve face areolae (Fig. 69).

Gomphonema acuminatum and G. coronatum EHRENBERG were typified by JAHN \& KUSBER (2004, figs 20, 30 respectively). Both species have a strong constriction in the upper part of the valve that clearly differentiates it from G. gautieriforme. Gomphonema asiaticum LiU \& KocIOLEK in LiU et al. (2013, figs 45-60) is characterized with triundulate margins, distinctly constricted towards the headpole and broadly rhomboid to even quadrangular with a protracted and rostrate apex headpole. Gomphonema gautieriforme can be easily differentiated from the latter by the shape of apices and the valve outline.

\section{Acknowledgement}

The authors want to express their gratitude to Erwin Reichardt for his useful comments on the early version of the manuscript. This study was founded by the Alexander von Humboldt Foundation and SYNTHESYS program. We would like to express our gratitude to Dr. David M. Williams, Department of Botany, The Natural History Museum, London, for useful discussions and English corrections. We also thank Friedel Hinz from the Friedrich Hustedt Diatom Study Centre, Bremerhaven for loan of the type material of G. brebissonii.

\section{REFERENCES}

Agardh, C.A. (1824): Systema Algarum. - Lundae, xxxvii $+312 \mathrm{pp}$.

Bruder, K. \& Medun, L.K. (2008): Morphological and molecular investigations of naviculoid diatoms. II. Selected genera and families. - Diatom Research 23: 283-329.

Cholnoky, B.J. (1957): Über die Diatomeenflora einiger Gewässer in den Magalies-Bergen nahe Rustenburg (Transvaal). - Botaniska Notiser 110: 326-362.

Cleve-Euler, A. (1955): Die Diatomeen von Schweden und Finnland. Part IV. Biraphideae 2. - Kongliga Svenska Vetenskaps-Akademiens Handligar ser. 4, 5: 1-232, figs 971-1306.

Dawson, P.A. (1974): Observations on diatom species transferred from Gomphonema C.A. AgardH to Gomphoneis CLEVE. - British Phycological Journal 9: 75-82.

EhrenberG, C.G. (1832): Über die Entwicklung und Lebensdauer der Infusionsthiere; nebst ferneren Beiträgen zu einer Vergleichung ihrer organischen Systeme. - Abhandlungen der Königlichen Akademie der Wissenschaften zu Berlin 1831: 1-154, 4 pls.

EhrenberG, C.G. (1838): Die Infusionsthierchen als vollkommene Organismen. Ein Blick in das tiefere organische Leben der Natur. - Verlag von Leopold Voss, Leipzig. pp. 1-xvii, 1-548, pls. 1-64.

Ehrenberg, C.G. (1854): Mikrogeologie. Einundvierzig Tafeln mit über viertausend grossentheils colorirten Figuren, Gezeichnet vom Verfasser. - Leopold Voss, Leipzig. 40 pls.

Elmore, J.C. (1921): The diatoms (Bacillarioideae) of Nebraska. - University Studies, January-October, The University of Nebraska, Lincoln 21: 22-214, 23 pls.
Foged, N. (1982): Diatoms in Bornholm, Denmark. Bibliotheca Phycologica 59: 1-175.

Fourtanier, E. \& Kociolek, J.P. (2011): Catalogue of Diatom Names. On-Line Version. Updated 19 September 2011. - http://research.calacademy.org/research/ diatoms/ names/index.asp

Hustedt, F. (1930): Bacillariophyta (Diatomeae). In: PAscher, A. (ed.): Die Süsswasser-Flora Mitteleuropas. Zweite Auflage. Heft 10. - 466 pp., 875 figs, Gustav Fischer, Jena.

Hustedt, F. (1945): Diatomeen aus Seen und Quellgebieten der Balkan-Halbinsel. - Archiv für Hydrobiologie 40: 867-973, 12 pls.

JAHN, R. (1986): A study of Gomphonema augur EHRENBERG: the structure of the frustule and its variability in clones and populations. - In: Ricard, M. (ed.): Proceedings of the $8^{\text {th }}$ International Diatom Symposium, Paris, August 27 - September 1, 1984. - pp. 191-204, Koeltz Scientific Books, Koeningstein.

JAHN, R. \& KusBer, W.-H. (2004): Algae of the Ehrenberg collection - 1. typification of 32 names of diatom taxa described by C.G. EhrenBerg. - Willdenowia 34: 577-595.

Kermarrec, L.; Ector, L.; Bouchez, A.; Rimet, F. \& Hoffmann, L. (2011): A preliminary phylogenetic analysis of the Cymbellales based on 18S rDNA gene sequencing. - Diatom Research 26: 305-315.

Kociolek, J.P.; Kulikovskiy, M.S. \& Solak, C. (2013): The diatom genus Gomphoneis Cleve (Bacillariophyceae) from Lake Baikal, Russia. - Phytotaxa 154: 1-37.

Krammer, K. \& Lange-Bertalot, H. (1985): Naviculaceae. Neue und wenig bekannte Taxa, neue Kombinationen und Synonyme sowie Bemerkungen $\mathrm{zu}$ einigen Gattungen. - Bibliotheca Diatomologica 9: 1-230.

Krammer, K. \& Lange-Bertalot, H. (1986): Bacillariophyceae 1. Teil: Naviculaceae. - In: EтtL, H.; Gerloff, J.; Heynig, H. \& Mollenhauer, D. (eds): Süsswasserflora von Mitteleuropa 2/1. - 876 pp., Gustav Fischer Verlag, Stuttgart - New York.

Krammer, K. \& Lange-Bertalot, H. (2004): Bacillariophyceae 4. Teil: Achnanthaceae. Kritische Ergänzungen zu Achnanthes s.l., Navicula s.str., Gomphonema. Gesamtliteraturverzeichnis Teil 1-4. - In: Ettl, H.; Gärtner, G.; Gerloff, J.; Heynig, H. \& Mollenhauer, D. (eds): Süsswasserflora von Mitteleuropa 2/4. - 468 pp., Spektrum Akademischer Verlag, Heidelberg.

Lange-Bertalot, H. (1993): 85 neue taxa und über 100 weitere neu definierte Taxa ergänzend zur Süsswasserflora von Mitteleuropa, Vol. 2/1-4. Bibliotheca Diatomologica 27: 1-454.

Lange-Bertalot, H. (1995): Gomphosphenia paradoxa nov. spec. et nov. gen. und Vorschlag zur Lösung taxonomischer Probleme infolge eines veränderten Gattungskonzepts von Gomphonema (Bacillariophyceae). - Nova Hedwigia 60: 241-252.

Lange-Bertalot, H. \& Genkal, S.I. (1999): Diatoms from Siberia I - Islands in the Arctic Ocean (YugorskyShar Strait). - Iconographia Diatomologica 6: $1-303$.

Levkov, Z. \& Stojanovski, P. (2002): Changes in diatom flora in Doiran Lake in past 13 years. - Annual Biology 53: $22-38$.

Levkov, Z. \& Williams, D.M. (2011): Fifteen new diatom (Bacillariophyta) species from Lake Ohrid, 
Macedonia. - Phytotaxa 30: 1-41.

Levkov, Z. \& Williams, D.M. (2012): Checklist of diatoms (Bacillariophyta) from Lake Ohrid and Lake Prespa (Macedonia), and their watersheds. - Phytotaxa 45: $1-76$.

Levkov, Z.; Krstic, S.; Nakov, T. \& Melovski, L. (2005): Diatom assemblages on Shara and Nidze Mountains, Macedonia. - Nova Hedwigia 81: 501-538.

Levkov, Z.; Krstic, S.; Metzeltin, D. \& Nakov, T. (2007): Diatoms of Lakes Prespa and Ohrid. About 500 taxa from ancient lake system. - Iconographia Diatomologica 16: 1-611.

Liu, Y.; Kociolek, J.P. \& Wang, Q. (2013): Six new species of Gomphonema Ehrenberg (Bacillariophyceae) species from the Great Xing'an Mountains, Northeastern China. - Cryptogamie, Algologie 34: 301-324.

Mayer, A. (1913): Die Bacillariaceen der Regensburgen Gewasser. Systematischer Teil. - Berichte des Naturwissenschaftlichen (früher ZoologischMineralogischen) Vereines zu Regensburg 14: $1-364$.

MAYER, A. (1928): Die bayerischen Gomphonemen. - Denkschriften der Koniglich-Baierischen Botanischen Gesellschaft in Regensburg 17: 83-128, pls. 1-5.

Meduin, L.K. \& Round, F.E. (1986): Taxonomic studies of marine gomphonemoid diatoms. - Diatom Research 1: 205-225.

Metzeltin, D.; Lange-Bertalot, H. \& Nergui, S. (2009): Diatoms in Mongolia. - Iconographia Diatomologica 20: $1-684$.

Novais, M.H.; Blanco, S.; HlúBiková, D.; Falasco, E.; Gomà, J.; Delgado, C.; Ivanov, P.; Ács, É.; Morais, M.; Hoffmann, L. \& Ector, L. (2009): Morphological examination and biogeography of the Gomphonema rosenstockianum and G. tergestinum species complex (Bacillariophyceae). - Fottea 9: 257-274.

Oнtsuka, T. (2002): Checklist and illustration of diatoms in the Hii River. - Diatom 18: 23-56.

Patrick, R. \& Reimer, C.W. (1975): The diatoms of the United States exclusive of Alaska and Hawaii. Vol. 2, Part 1. Entomoneidaceae, Cymbellaceae, Gomphonemaceae, Epithemiaceae. - Monographs of the Academy of Natural Sciences of Philadelphia 13: $1-213$.

REICHARDT, E.(1999):ZurRevision der Gattung Gomphonema. Die Arten um G. affine/insigne, G. angustatum/ micropus, G. acuminatum sowie gomphonemoide Diatomeen aus dem Oberoligozän in Böhmen. Iconographia Diatomologica 8: 1-203.

ReIchardt, E. (2001): Revision der Arten um Gomphonema truncatum und G. capitatum. - In: JAHN, R.; Kociolek, J.P.; WitKowski, A. \& Compère, P. (eds): Lange-Bertalot-Festschrift: Studies on Diatoms. Dedicated to Prof. Dr. Dr. h.c. Horst Lange-Bertalot on the occasion of his $65^{\text {th }}$ Birthday. - pp. 187-224, A.R.G. Gantner Verlag. K.G., Ruggell.

ReICHARDT, E. (2005): Die Identität von Gomphonema entolejum Østrup (Bacillariophyceae) sowie Revision änlicher Arten mit weiter Axialarea. - Nova Hedwigia 81: 115-144.

ReIchaRdt, E. (2007): Neue und wenig bekannte Gomphonema-Arten (Bacillariophyceae) mit Areolen in Doppelreihen. - Nova Hedwigia 85: 103-137.
Ross, R. \& Sims, P.A. (1978): Notes on some diatoms from the Isle of Mull, and other Scottish localities. Bacillaria 1: 151-168.

Round, F.E.; Crawford, R.M. \& Mann, D.G. (1990): The diatoms: Biology and Morphology of the genera. 747 pp., Cambridge, Cambridge University Press.

Schumann, J. (1867): Die Diatomeen der Hohen Tatra. - Verhandlungen der Kaiserlich-Königlichen Zoologisch-Botanischen Gesellschaft in Wien 17: $1-102,4$ pls.

Tus, A. (2005): Taxonomy of the Gomphoneis tetrastigmata species complex. - Bulletin of the National Science Museum. Series B, Botany 31: 89-108.

Ueyama, S. \& Kobayasi, H. (1988): Two Gomphonema species with strongly capitate apices: G. sphaerophorum Ehr. and G. pseudosphaerophorum sp. nov. - In: Round, F.E. (ed.): Proceedings of the Ninth International Diatom Symposium. - pp. 449-458, Biopress Ltd., Bristol, and Koeltz Scientific Books, Koenigstein.

VAn de ViJver, B. \& McBride, P. (2006): Gomphonema isabellae VAN DE VIJVER sp. nov., a new freshwater diatom species from sub-Antarctic Macquarie Island (southern Pacific Ocean). - Diatom Research 21: 441-449.

Van de Vijver, B.; Jarlman, A.; de Haan, M. \& Compère, P. (2013): The ultrastructure of Gomphonema augur and Gomphonema gautieri (Bacillariophyta). Cryptogamie, Algologie 34: 103-116.

VAn Heurck, H. (1880): Synopsis des Diatomées de Belgique, Atlas. - pls 1-30, Ducaju \& Cie, Anvers.

Van Heurck, H. (1885): Synopsis des Diatomées de Belgique. Texte - 235 pp., Martin Brouwers \& Co., Anvers.

(C) Czech Phycological Society (2014)

Received March 11, 2014

Accepted May 12, 2014 